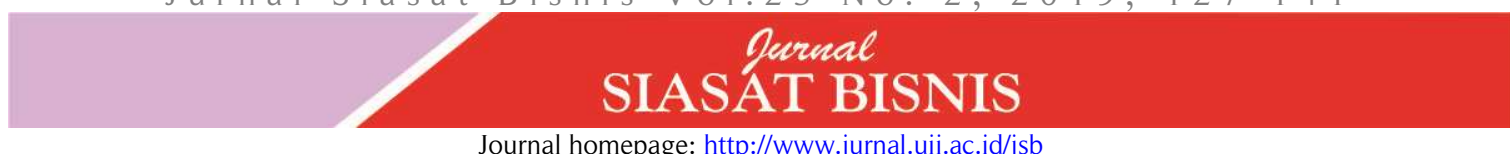

Journal homepage: http://www.jurnal.uii.ac.id/jsb

\title{
Gamified training: a new concept to improve individual soft skills
}

\author{
Ardian Adhiatma, Tina Rahayu*, Olivia Fachrunnisa \\ Universitas Islam Sultan Agung, Semarang, Indonesia \\ *Corresponding author: tinarahayu@std.unissula.ac.id
}

\begin{abstract}
This study discusses a new concept of "gamified training" through creative-oriented leadership. This concept aims to improve individual soft skills, such as communication skills, creative intelligence and collaboration skills. Gamified training is a design of training through gamification so that it will produce an effective and targeted training. Gamification is a training policy using game pattern. The sampling technique used purposive sampling method. The 106 respondents were involved in this study. Data collection technique used questionnaires and analyzed by regression method. The results showed that there was significant positive effect between creativeoriented leadership with gamified training. Furthermore, gamified training has also been proven to improve the individual soft skills.
\end{abstract}

Keywords:creative-oriented leadership, gamified training, communication skills, creative intelligence, and collaboration skills.

JEL Classification Code: M12, M53 DOI: 10.20885/jsb.vol23.iss2.art5

\section{Introduction}

The era of industrial revolution 4.0 greatly influences the development of work. Individuals who become members of an organization are required to be more creative and innovative (Cartensen \& Salzmann, 2016) in completing their work to face job challenges in the business world. One of the skills that must be possessed by individuals is individual soft skills. A work with soft skills is able to offer opportunities to develop professionalism, get new ideas, learning experiences, ease of communication and network support. Individuals must have soft skills such as communication skills, creative intelligence, and collaboration skills in order to support their work productivity (Gordon, 2002). These soft skills can be obtained through training which is conceptualized with gamification or called gamified training. Currently, gamified training is often applied in education, but in this study, gamified training is at world of work in order to increase soft skills with completing work.

There are many potential tools that can be used to design better training and gamification has become a choice that is often chosen rather than redesign traditional training (Denny, 2013). Gamification does not replace existing training methods but improves methods that are less effective. Hence, it improves individual soft skills. Gamification is the use of game elements and game design techniques in non-game contexts (Deterding et al., 2011). Gamification is an element of the game that has fun concept in the workplace to increase reaction and involvement with the subject matter (Denny, 2013); (Landers \& Callan, 2011). Gamification in training methods is made to produce the desired changes. Some types of training that currently being applied in organizations may begin to experience burnout, such as on the job training and off the job training methods. Those methods are less relevant with the digitalization era that requires new innovations in training. It is because millennial workforce currently needs interesting training concepts so that they do not feel bored in the process of knowledge transfer from the trainer. It makes them capture the knowledge clearly and applied at work (Armstrong \& Landers, 2017). Dhar (2015) mentioned 13 methods of training. One training method that suits a competitive business world is game-based training, which offers a cheap but effective alternative training (Wilson et al., 2009). Galetta et al (2014) state that gamified training is a new training that is able to save costs in order to maximize performance in training. The competitive business organizations 
need to adopt game-based training so that participants in this digital era are increasingly challenged to improve their soft skills which can affect their performance for the organization (Adams \& Makramalla, 2015).

Armstrong \& Landers (2017) showed that the elements of gamification are points, badges, leader boards, challenges, and rewards. It can be used to determine learning outcomes. By challenging the trainees to learn, they will provide the best effort during learning. By involving trainees in game, they may be more interested with the content, thus it increases their efforts. If it is applied in the training method, each person will get points and rank according to their achievements in following and completing the challanges of training. Participants will also get rewards for the achievements they have obtained after attending the training. As the result, the contents of the gamification can increase their competition in increasing soft skills. In several studies, gamification is able to improve these soft skills. Elements that must be considered in designing the gamified training are determining training needs, training designs that must be aligned with the specified training needs (including the use of game elements) or measuring the problems or trainees' motivation. The success of gamified training is determined by these elements. If one of the identified elements is not right, then it will likely fail. A leader must be able to analyze appropriate training needs and material and good game techniques so that training becomes more effective. Hence, it needs a certain style of leadership to drive the existance of innovative training. One of them is creative-oriented leaders.

Creative-oriented leaders are certainly able to create conditions where the game is applied in a variety of training so that it triggers an increase in individual soft skills to create work innovation. Leaders must be able to attract the attention of individuals to be creative and help individuals to maintain the efforts while struggling to the goal of creativity (Zhang \& Bartol, 2010). Leaders can encourage creativity by rewarding and recognizing members who produce creative results (Baer, Oldham, \& Cummings, 2003). Creative leaders are proven to be able to encourage members to become creative too. The members see their leader as role model who can push for a better levels of soft skills (David et al., 2014). Such leaders are predicted to be able to create a gaming atmosphere that is expected to improve the members soft skills such as communication skills, creative intelligence and collaboration skills.

Moreover, communication skills are the basic things that individuals need to have at work. Good communication skills are proven to improve work completion by having quality discussions with each other and avoiding misunderstandings and conflicts between individuals (Galetta et al., 2014). In addition, individuals must be creative intelligent in facing the uncertain business world. When their level of creativity increases, they can create work completion innovations and create opportunities that benefit the organization (Zimmerer and Scarborough, 2008). Work completion can also be achieved through collaboration among individuals so that the ability to collaborate with each other will maximize work productivity.

Although there are a lot of discussion with regard of training benefits for work achievement, the study about gamified training and creative oriented leadership has not been much studied and there have not been many theoretical studies, especially in the business context. Hence, it brings an opportunity to discuss these contexts deeper and especially to analyze the impact on individual soft skills (communication skills, creative intelligence and collaboration skills). Keep in mind that not all industries fit the concept of gamifed training. Gamifed training presents many methods in a game that is intended to increase creativity so that it is suitable when applied in the creative industry. Creative industries are considered very necessary to implement gamified training because they have the same orientation based on individual creativity. Testing is done in organizations that are oriented to creativity such as fashion, beauty and cosmetics so that it may be relevant to the training needs that can foster the creativity of individuals in the organization. 


\section{Literature Review}

\section{Creative Oriented Leadership and Gamified Training}

Creative oriented leadership is a style to develop the organization in a new direction that is more profitable, has the ability to promote positive change and inspire subordinates to become creative individuals (Sternberg, 2007). Creative leaders are leaders who can motivate followers to engage in creative processes and produce creative results (Tierney, 2008). The leader must respect the creative ideas proposed by the individual for the organization. Besides that, leaders should also be able to encourage the members to think creatively and be able to develop their ideas to be implemented for the effectiveness of performance and organizational development. Such emphasis tends to be the main concern of the individual and facilitates the efforts to be creative. Organizations that successfully grow talent are organizations that focus on individual development and knowledge (Harris, 2008). A creative-oriented leader must be able to create an atmosphere or stimulus to individuals that lead to creativity and aims to improve their soft skills that can be obtained through gamified training.

Training is a function of human resources that must be available in organizational lines. As the result the leader needs to be creative oriented so that the training is effective and in accordance with the needs of the participants. Gamifed training is the novelty of traditional training so it requires creativity in compiling it. Stoll (2007) explains that creative leaders regulate the tone, climate and conditions under which creativity can develop. This includes developing a type of training that triggers creativity, collaboration and communication between participants. Bosiok \& Sad (2013) said that creative leaders are able to capture ideas that provide opportunities for organizational effectiveness such as game-based training. Werbach (2014) define gamification as the process of making the game active and having much fun. It reflects the use of game pattern including progress mechanisms (such as point systems), player control, rewards, collaborative problem solving, stories, and competition in non-game context (Deterding et al., 2011; Kapp, 2014). Training is defined as an activity that leads to the acquisition of knowledge, skills, and attitudes that are relevant to direct and future work or roles (Kraiger and Culbertson, 2013). Such activities may include education or training courses in the workplace under close supervision. After the training is complete and individual works in the organization, the level of performance must be maintained to achieve organizational results (e.g. product quotas, financial goals, etc).

The application of gamification in Human Resource Management is used to identify which game elements can be applied to non-game contexts either individually or in groups. In the gamified training concept, success in utilizing games for learning and game pattern has a major impact on the learning outcomes in training at work. Integrated training is the integration of game elements into training content or training methodology. As an example of gamified training content (Armstrong and Landers, 2017) collaborates on technology security training programs by incorporating elements of fiction (i.e. stories) into the content without changing other aspects of the training method. In the field of training, game pattern has been applied to increase effectiveness in overall training and to increase motivation during training. Thought games in training can have an impact on learning outcomes and organizations (Armstrong and Landers, 2016).Training is said to be effective if the skills and behaviors learned and practiced during the training can be transferred to the workplace and can be applied in the context of work. It must also be maintained over time and can be generalized in all contexts (Holton and Baldwin, 2003). The results show that to improve training transfers, organizations must design training that gives trainees the ability to transfer learning, strengthen training participants' confidence in their ability to transfer, ensure that training content is maintained over time, and provide appropriate feedback regarding job performance employee after training activities. Creative-oriented leader is able to design interesting training so that they can increase participants' motivation during training.

$\mathrm{H}_{1}$ : Creative Oriented Leadership has a significant positive effect on gamified training. 


\section{Gamified Training and Communication Skills}

Procurement of training with the gamification concept can improve individual communication skills in the group. Communication skill is skill in using language and nonverbal communication that play the most effective role in the realization of communication (Deniz, 2007). Communication is not only limited to the words spoken. This involves nuances such as telephone skills, presenting, giving and receiving criticism, motivating and supporting, persuading and negotiating, gathering information, listening, and body language (Woodcock and Crow, 2010).

Providing training with the gamification concept is intended to enable participants to explore themselves so that their communication skills are better. The challenges conceptualized by gamification also motivate participants to explore their capabilities. Gamification has proven to be effective in activating user interests positively, motivating choices, stimulating creative insights in problem-solving, improving decision making, predicting future scenarios, transferring knowledge, developing individual skills, gaining knowledge, and building communities (Garris et al., 2002).

Training that is conceptualized using gamification is expected to be able to develop individual skills, including improving the ability to communicate and exchange ideas well so that there will be no mistakes in group communication. Simões, Díaz, and Fernández, (2013) stated that gamification can improve the ability to share knowledge gained through social interaction. After training with game concept, participants will be motivated to improve their quality well and can share their knowledge with others in a group. If advancements in gamification can be used as a form of instant feedback to achieve goals, ranking boards can be as a tool to facilitate desired behaviour such as sharing knowledge and contributing to a collection of knowledge (Shpakova et al., 2017). The concepts offered by gamification will trigger participants to go ahead and become superior. This can increase their knowledge during training and allow them to share it with others. According to McGonigal (2011), gamification can create social connectivity that can encourage conversation and knowledge sharing. In a training consisting of several people, it will trigger to communicate well. The games included in the training will make participants interact more. Osipov, Volinsky, Nikulehev, and Prasikova, (2015)stated that gamification can improve communication and interaction among participants both in the group and outside the group.

The training conceptualized by gamification allows improving participant communication. Osipov et al., (2015) proved that there is an increase in the communication capabilities of users in the application of gamification in an e-learning application. But such system is not all suitable for every user, because some people are very shy and cannot communicate with strangers, even when provided with a communication scenario predetermined in the e-learning application. Training designed based on game pattern will improve quality and communication skills such as the ability to transfer other knowledge from their subordinates.

$\mathrm{H}_{2}$ : Gamified training has a significant positive effect on communication skills.

\section{Gamified Training and Creative Intelligence}

Creative is defined as the development of ideas, products that are new, original, and which have practical value, usability, or appropriateness (Gino and Ariely, 2012). Whereas according to Zimmerer and Scarborough (2008), creative is defined as the ability to find new ways to create opportunities that benefit the organization. Akinboye (2002) defined creative as an individual's ability to create new ideas, new designs, and new concepts, update old ideas into unique ideas, and have unusual ways of completing work. Santrock (2007) defined intelligence as a skill to solve problems, the ability to adapt to new things and from everyday experiences. Another definition of intelligence is a single and general ability that is owned by someone at different levels and applied to several tasks (Ormond, 2009). An individual who is able to create new ideas is predicted to be able to solve problems with various solutions to be effective. Based on the definition of these experts, creative intelligence can be defined as the ability to think and act creatively in completing work. 
The impact of gamification can result at innovation and a change in knowledge management, give effective improvements to the process of social learning and increasing creativity (Ninaus et al., 2015). Gamified training will trigger participants' creativity in completing training levels. McGonigal (2011), states that game factors that can facilitate and enhance the transmission of knowledge, social learning and encourage people to behave positively (best practices). McGonigal said: "When we're playing games, we're not suffering", which means that gamification is able to reduce stress levels in the execution of tasks, enable better concentration, activate attention mechanisms in problem-solving by stimulating new ideas and creative solutions.

Gamified training is expected to be able to make participants more creative after attending the training. They easily complete the work because of the creative process they are going through. Gamification can increase the creativity of the players because they are required to complete the game (Kapp, 2014). Kapp (2014), mentioned that gamification can trigger elaboration (linking new information with previous information). Gamified training will trigger participants to think creatively such as characterized by elaboration. This can help individuals to complete their work in the presence of prior experience and current circumstances. Burke (2012) mentions that gamification can design behavior, develop skills, or involve people in innovation. The emergence of innovation is caused by the presence of creative ideas produced by someone due to the influence of gamification. Gamification is able to motivate people to always want to be champions so that the gamified training process will shape employees to always want to be ranked first. A culture like this will affect their performance so that the work will be maximized. According to Landers and Landers (2014), gamification can encourage and enhance learning effects. Werback and Hunter (2012), believed that the gamification mechanism can also lead to the acquisition of knowledge so that it can improve their quality. The concept of gamified training requires individuals to think creatively so that they complete the challenges given by trainers who can later be applied in the workforce.

$\mathrm{H}_{3}$ : Gamified Training has a significant positive effect on creative intelligence.

\section{Gamified Training and Collaboration Skills}

Ramus and Vaccaro (2017), defined collaboration as participation in a meeting and sharing information to identify common solutions for complex tasks. Collaboration is the act of working in a team for a common goal (Collins et al., 2010). Collaboration is also defined as a process in which two or more parties work to achieve mutually beneficial results. It also aims to build the intrinsic motivation and trust in order to facilitate the creation of shared ideas or knowledge (Miles et al., 2005). Collaboration must consider that all team members must demonstrate strong communication skills, the ability to share knowledge, and the willingness to find time to support teamwork where all members are responsible. So collaboration skills can be defined as the ability to work in teams that show strong communication skills, the ability to share knowledge, and a willingness to find time to support teamwork where all members are responsible.

Zicherman and Cunningham (2011), said that when used to increase individual involvement, gamification can improve teamwork and change routine tasks that are often tedious by motivating individuals through games and competition in the same team and across teams. Training can link collaboration skills to teamwork within the organization. Gamification reflects the use of game pattern including progress mechanisms (such as point systems), player control, rewards, collaborative problem solving, stories, and competition in non-game context (Deterding et al., 2011).

Marczewski (2012), stated that gamification can make teamwork more compact in completing their work. Kay, Yacef, Maisonneuve, and Reimann (2006), also mentioned that games are able to bring more motivation and involvement and increase one's collaboration and interaction. Blohm and Leimeister (2013) explains game mechanism and collaboration. Games pattern can make team work cooperate well and they can finish their work effectively.

$\mathrm{H}_{4}$ : Gamified Training has a significant positive effect on collaboration skills. 


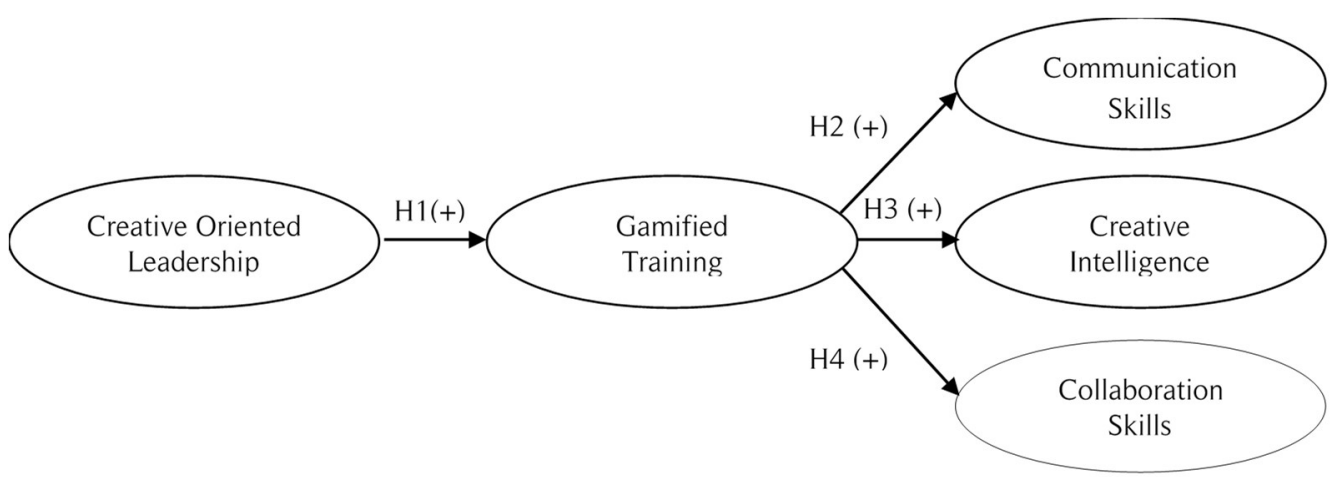

Figure 1. Research Model

\section{METHOD}

\section{Data}

The population in this study was industry engaged in the field of creativity, such as fashion, accessories, and beauty cosmetics in Indonesia. These fields were chosen because they include creative industries which require attractive training to create individuals who have a high level of creativity. In addition, leaders in the creative industries certainly have a high level of creative intelligence and it is often oriented with the members' creativity. The population in this study is amount unknown, so the questionnaire distributed were 180. In total 155 questionnaires were filled by respondents, but only 106 (59\%) questionnaires were valid because many data were not relevant to the characteristics used in this study. The sampling technique used in this study was purposive sampling. This sampling pays attention to population characteristics so that samples representation (Rahi, 2017). The characteristics of the sample are individuals who work in creative industries where they are demanded to have high creativity and have worked for at least 6 months.

The data source in this study used primary data. The primary data source is data obtained from the first source of information so that a researcher can collect the relevant data (Emmanuel and Ibewawuchi, 2015). Primary data of this study were obtained from the distribution of questionnaires to individuals who worked in cosmetic companies for $4 \%$, individuals who worked in the field of fashion and medicine for $66 \%$, and individuals who worked in the beauty sector for $30 \%$. The primary data obtained is the respondents' perceptions of creative oriented leadership, gamified training, communication skills, creative intelligence, and collaboration skills.

\section{Measures}

\section{Creative oriented leadership}

Creative Oriented Leadership is a leadership style that direct the members to have a creative attitude, provide opportunities and facilities that encourage the member's activity creativity. Variable measurement consists of 6 items, they are 1) Receiving new ideas from subordinates without scathing criticism 2) Willing to explore subordinate ideas that seem not promising 3) Encouraging renewal of the process of making new products 4) Encouraging updates on new ways of working 5) Encouraging the creation of new ideas for completing work 6) Encouraging changes to fundamental changes in existing products and services. These indicators were adapted from the research of Amabile (1985) and (Ahmadi \& Nasirivahed, 2007). The indicators measured by using a Likert scale of $1=$ strongly disagree to $5=$ strongly agree.

\section{Gamified training}

Gamified training is training given to organizational members using game pattern, starting from determining needs, preparing facilities, materials, locations and post-training rewards. There are 6 
indicator items adopted from Palmer, Lunceford, and Patton (2012) and (Dahar, 2015),they are; 1) Training determined by participants' proposals 2) Forms of training according to participants' needs 3) Training facilities in accordance with participants' proposals 4) Training materials designed according to the tastes of participants 5) Trainers understand the training needs needed by participants 6) Participants get training rewards when they reach the target in training.

\section{Communication skills}

Communication skills are skills to express meaning to others to reach agreement and skills to use language and nonverbal communication that reflect the skills of building effective communication. Indicators were adopted from (Ferguson, 2002) and (Iksan et al., 2012)consist of 8 items, namely 1) Communication ability to complete work through oral 2) Communication ability to complete work through writing 3) Communication ability to complete work through body language 4) Ability to provide feedback in communicating with others verbally 5) Ability to provide feedback in communicating with others in writing 6) Ability to provide feedback in communicating with others through body language 7) Ability to achieve mutual understanding 8) The ability to reach agreement when communicating.

\section{Creative intelligence}

Creative intelligence is the ability to think and act creatively in completing work. Five-point Likert scale with 4 items was adopted from (Torrance, Fitzgerald, and Batson, 2000) and (Woodcock and Crow, 2010)including 1) Ability to produce new ideas or ideas that do not exist previously to complete work 2) Ability to learn new things 3) Ability to obtain and use knowledge from anywhere 4) Ability to adjust requests requested by consumers.

\section{Collaboration skills}

Collaboration skills are the ability to work in team that show strong communication skills, the ability to share knowledge, and the willingness to find time to support teamwork where all members must be responsible. This is measured by using 6 items obtained from (Bosch-Sijtsema, Rouhomaki, and Vartiainen, 2010; Fruchter and Ponti, 2010; Dyer and Reeves, 2000) they are; 1) the ability to cooperate in a team to achieve common goals 2) the ability to motivate members in a team 3) the ability to adjust to group dynamics 4) the ability to avoid issues that harm the group 5) the ability to overcome misunderstandings that exist in a team 6) the involvement in solving problems in a team.

\section{Results}

\section{Descriptive statistics and hypotheses testing}

The data was analyzed using SPSS 22 software program. The use of this software makes the researchers easier to find out whether the proposed hypothesis will be accepted or rejected. Data analysis techniques used included descriptive statistics, Pearson product-moment correlations, multiple regression and absolute difference in reliability and moderation. Table 1 describes descriptive statistics and discriminant validity.

Table 1. Summary of Descriptive Statistics

\begin{tabular}{lcclllll}
\hline Variable & Means & SD & COL & GT & CS & CI & ColS \\
\hline Creative Oriented Leadership (COL) & 3,94 & 3,519 & 1 & & & & \\
Gamified Training (GT) & 3,48 & 3,844 & $0,350^{*}$ & 1 & & & \\
Communication Skills (CS) & 3,87 & 4,553 & $0,560^{*}$ & $0,496^{*}$ & 1 & & \\
Creative Intelligence (CI) & 4,03 & 2,244 & $0,473^{*}$ & $0,344^{*}$ & $0,706^{*}$ & 1 & \\
Collaboration Skills (ColS) & 4,06 & 3,387 & $0,518^{*}$ & $0,442^{*}$ & $0,705^{*}$ & $0,715^{*}$ & 1 \\
\hline
\end{tabular}

Note: *Correlation is significant at the 0.05 level 
Table 2. Summary of Hypotheses Testing

\begin{tabular}{llllllll}
\hline Hyp & $\begin{array}{c}\text { Dependent } \\
\text { Variable }\end{array}$ & $\begin{array}{c}\text { Independent } \\
\text { Variable }\end{array}$ & Beta & T-Test & $\mathrm{R}^{2}$ & F-Test & Conclusion \\
\hline H1 & Gamified Training & $\begin{array}{l}\text { Creative } \\
\text { Oriented } \\
\text { Leadership }\end{array}$ & $0,382^{*}$ & $3,812^{* *}$ & 0,123 & $14,528^{* *}$ & $\begin{array}{l}\text { Supported- } \\
\text { positive and } \\
\text { significant effect }\end{array}$ \\
H2 & $\begin{array}{l}\text { Communication } \\
\text { Skills }\end{array}$ & $\begin{array}{l}\text { Gamified } \\
\text { Training }\end{array}$ & $0,588^{*}$ & $5,827^{* *}$ & 0,246 & $33,952^{* *}$ & $\begin{array}{l}\text { Supported- } \\
\text { positive and } \\
\text { significant effect }\end{array}$ \\
H3 & $\begin{array}{l}\text { Creative } \\
\text { Intelligence }\end{array}$ & $\begin{array}{l}\text { Gamified } \\
\text { Training }\end{array}$ & $0,201^{*}$ & $3,741^{* *}$ & 0,119 & $13,996^{* *}$ & $\begin{array}{l}\text { Supported- } \\
\text { positive and } \\
\text { significant effect }\end{array}$ \\
H4 & Collaboration Skills & $\begin{array}{l}\text { Gamified } \\
\text { Training }\end{array}$ & $0,389^{*}$ & $5,020^{* *}$ & 0,195 & $25,204^{* *}$ & $\begin{array}{l}\text { Supported- } \\
\text { positive and } \\
\text { significant effect }\end{array}$ \\
& & & & & & & \\
\end{tabular}

Notes; * (beta) **sig at $\mathrm{p}<0,05$

Table 2 shows the results of hypothesis testing. Hypothesis 1 shows a significant positive effect between gamified training and creative oriented leadership. This is indicated by the existence of a significant value of $0,000(p<0.005)$ with $t$-count value of 3.812 (t-count $>1.6596)$ and coefficient of 0.382 so that this hypothesis is accepted. This is possible if a leader is oriented with creativity, accepts new ideas from members, is willing to explore subordinate ideas, is able to encourage renewal of the process of making new products, update new ways of working and new ideas of conceptual training. So that, it produced a training that can motivate individuals to do tasks pleasantly and interestingly, and maximize their learning and retention. This supports the research of Kiryakova, Angelova, and Yordanova (2014)about gamification in education, teachers who are able to think creatively and understand the needs of their students are able to create gamified training to motivate and engage them in learning. This allows a leader who is oriented to creativity to be able to create gamified training for his subordinates.

Hypothesis 2 states that there is a significant effect between gamified training and communication skills. Based on the table above, the significance value is $0,000(p<0,005)$ with a tcount value of 5.827 (t-count> 1.6596) and a coefficient value of 0.588 . So that this hypothesis is accepted, if the company implements training that is determined by the participants' proposals, according to the needs and tastes of the participants and giving rewards as appreciation for the participants during the training allows participants to improve their ability to communicate both orally, textually, and body gestures. The concept of gamified training can improve the ability to communicate with others so that work becomes easier with sharing experiences. This supports the research of Fisher (2007); Russell and Fisher (2009), it is stated that games can improve technical communication, crosscultural workplace communication(Robinson et al., 2000), logistics and supply chain management (Reiners et al., 2012), history (Corbeil and Laveault, 2011), and interpersonal relations (Witte, 2014).

The results of hypothesis 3 state that there is a significant positive effect between gamified training and creative intelligence. This is evidenced by the significance value of $0,000(p<0.05)$ with a t-count value of 3.741 (t-count> 1.6596) and a coefficient value of 0.201 so that $\mathrm{H} 3$ is accepted. The concept of gamification in training allows participants to think more creatively to solve challenges in training and motivates them to learn new things to achieve the rewards provided by trainers. This will be applied in the world of work so that work will be easy and produce new innovations for the emergence of these creative ideas. This is supported by the research of (Skarzauskiene, 2015)that defines gamification as one of methods that can encourage collective intelligence through collective 
creativity so that individuals can solve work problems well and bring innovation to existing business developments.

Hypothesis 4 states the influence of gamified training and collaboration skill. Based on table 2 , the significance value is $0,000(\mathrm{p}<0.05)$ with a $\mathrm{t}$-count value of 5,020 ( $\mathrm{t}$-count>1,6596) and a coefficient value of 0,389 . This shows a significant positive effect between gamified training and collaboration skills so that $\mathrm{H} 4$ is accepted. The effect of the gamification concept which gave rise to the ability to cooperate in a team is to achieve a common goal. Gamification also enables the ability to motivate others and increase individual involvement in solving problems in groups because of the implementation of game elements such as prizes, points, leaderboard, and achievement badge so as to increase collaboration skill within a team. In accordance with the research of (Li et al., 2013), gamification can foster a participatory approach and collaboration skill among colleagues and motivate participants to help each other to achieve common goals. Collaboration skill is very influential on the success of a team in completing work so it needs to be improved with a gamified training concept.

Finally, the table also shows the results of $\mathrm{R}^{2}$ for the research model. The findings indicate that a $12.3 \%$ variation in gamified training is caused by the presence of creative-oriented leadership. Then, gamified training can explain communication skill variable of $24.6 \%$, creative intelligence variable of $11.9 \%$, and collaboration skill variable of $11.5 \%$.

Table $\mathrm{F}$ explains whether there is an influence between the independent variables and the dependent variables. Hypothesis 1 has a significance value of $0,000(p<0.05)$ with F-count of 14,528 (F-count $>3.93)$. Hypothesis 2 shows a significance value of $0,000(p<0.05)$ with F-count of 33,952 (F-count> 3.93). Hypothesis 3 shows a significance value of $0,000(p<0.05)$ with F-count of 13,996 (F-count> 3.93). Hypothesis 4 shows a significance value of $0,000(p<0.05)$ with F-count of 25,204 (F-count> 3.93). Therefore, the model used in this study is feasible or fit.

\section{Discussion and Conclusion}

This study contributes to the literature on the concept of gamified training. It is specifically integrating the concept of gamified training and individual's soft skills in an organization through creative creativity. Creative-oriented leadership is proven to be able to create a pleasant training atmosphere such as gamification. A leader who is oriented towards creativity has the ability to conceptualize training with great interest so as to achieve efficiency. Some individuals who have different needs and tastes must be analyzed carefully so that training is on target so that they can maximize performance after getting training. Then as technology develops, leaders must also be able to develop their subordinates' ability to optimize their skills through good training.

In addition, gamified training can improve the communication skills of participants because gamification stimulation directs them to exchange information and discuss about how to complete games in the context of training. Osipov et al., (2015) prove that there is an increase in the communication capabilities of users in the application of gamification in an e-learning application. Gamification is felt to be able to improve communication and interaction between participants both within and outside the group. Communication skills possessed by individuals will greatly influence the results of their performance and allow them to exchange experiences of new ways of working and new ideas in completing work.

The application of the game on training enhances individual creative intelligence. They will be motivated to produce ideas or innovations in solving challenges in training. The participants will try to explore their creativity to get the top in the training so that they get the desired reward. Burke (2012), mentioned that gamification can design behavior, develop skills, or involve people in innovation. Moreover, implementing certification in training can increase collaboration among participants so that it makes people easier to work together in achieving common goals.

This research contributes to the importance of using gamification in training. Our first contribution is that individual perceptions of their leaders reflect that their leaders accept individual 
ideas well. The leader was able to encourage the renewal of new ways of working for the existence of the company in competing. At present, the training provided by the company has been conceptualized in such a way without any proposals from subordinates. The gamified training tries to modify the training by giving rewards after participants complete the training. The reward after training has not been fully implemented so that individual motivation may be lacking. Leaders who are able to be oriented towards creativity are also proven to be able to create appropriate training for their subordinates so that they are right on target and get feedback on improving their performance after training.

Second contribution is that individual perceptions about the training currently provided by the company can improve their soft skills and make them easier to do their assignments both individually and in groups. Gamified training is proven to be able to improve their abilities which they can then apply in the real world of work. They have good communication skills and the creativity to create ideas so they can share with groups to complete the work.

The third contribution is addressed to the Creative industry to apply Gamified training. Creative industry such as fashion and beauty cosmetics companies can design training by giving opportunity for employee to have service skills to customer by wearing company products. For example, training on how to mix and match clothes and accessories that are appropriate to use and match the events determined by the trainer (for example formal, non-formal, and casual events). During the training, the participants presented the results on how to mix and match clothes in all the events that had been conceptualized by the previous trainer. The effect of this gamified training is that all participants try to practice and compete with others to further explore their knowledge and creativity in order to reach points and occupy the first rank so that they are rewarded by the trainer. This kind of effect can later be useful when participants serve the needs of fashion consumers deftly, helping to recommend an outfit that suits what consumers need.

Additionally, in the field of beauty cosmetics, participants were given training on how to apply makeup properly along with information about various cosmetics, various skin types and solutions to various skin problems and their solutions. Participants competing to show their results in decorating themselves in accordance with their respective skin conditions. The best application of makeup will be rewarded so that the competitive effect is very visible. This is what triggers them to improve various kinds of soft skills such as creativity, communication between peers and collaboration to solve existing problems, in this case is able to recommend and inform cosmetics what suits the needs of each consumer and also proficient in providing application examples to consumers if needed.

\section{Managerial Implication and Research Limitation}

The managerial implication obtained from this study is that a leader must have creativity oriented to be able to encourage members to think creatively. In addition, leaders must also create training that is conceptualized with gamification, so that the training becomes interesting and fun. Such fun training can foster an attitude of continuing to learn and improve the skills they have. These soft skills are very useful for creating efficient individual performance. But keep in mind that gamified training is not the single most effective training method. The organization must also adapt the training method to existing conditions and needs such as who will receive the training and how the training is appropriate for the participants at that time. The challenge is not just updating existing training methods, but also understanding what methods are needed by participants along with consideration of the analysis of the costs incurred and the results.

This study has several limitations such as the limited number of respondents and only covers the field of fashion and beauty. Then, distributing questionnaires online and indirectly makes the information collected is lacking. In selecting respondents, further researchers are recommended to select individuals who enter digital organizations who work in training centers as respondents in research. It is expected that they can use the gamified training concept if their clients use the training services they provide. Future studies may be able to examine the relationship of other variables that 
can improve gamified training such as Culture Innovation or Bleisure Motivation. The concept of gamified training that has been tested in this study can be further developed in the form of modeling concepts and experiments on training that are visualized with certain game techniques on certain research objects.

\section{References}

Adams, M., \& Makramalla, M. (2015). Cybersecurity Skills Training: An Attacker-Centric Gamified Approach Cybersecurity Skills Training : An Attacker-Centric Gamified Approach. January, 5-14.

Ahmadi, P., \& Nasirivahed, N. (2007). Strategic relationship effective on organizational innovation. Tadbir Magazine, (186), 38-42.

Akinboye, J. O. (2002). Creativity and innovation in business. Nigerian Journal of Applied Psychology, $7(1), 1-4$.

Amabile, T. M. (1985). Motivation and Creativity: Effects of Motivational Orientation on Creative Writers. Journal of Personality and Social Psychology, 48(2), 393-399.

Armstrong, M. B., \& Landers, R. N. (2016). Emerging Research and Trends in Gamification. In H. Gangadharbatla \& D. Z. Davis (Eds.), Gamifiying Recruitment, Selection, Training, and Performance Management: Game - Thinking in Human Resource Management (pp. 140165). Hersey PA, USA: IGI Global.

Armstrong, M. B., \& Landers, R. N. (2017). An evaluation of gamified training: using narrativeto improve reactions and learning', Simulation \& Gaming, 48(4), 513-538.

Baer, M., Oldham, G. R., \& Cummings, A. (2003). Rewarding creativity: When does it really matter? The Leadership Quarterly, 14(4), 569-586.

Blohm, I., \& Leimeister, J. M. (2013). Gamification: design of IT-based enhancing services formotivational support and behavioral change. Business and Information Systems Enginering, 5(4), 275-278.

Bosch-Sijtsema, P. M., Rouhomaki, V., \& Vartiainen, M. (2010). Multi-locational knowledge workers in the office: navigation, disturbances and effectiveness. New Technology, Employment and Work Journal, 25(3), 183-195. https://doi.org/10.1111/j.1468-005X.2010.00247.x

Bosiok, D., \& Sad, N. (2013). Leadership styles and creativity. 1, 64-77.

Burke, B. (2012). Gamification 2020: what is the future of gamification? https://doi.org/G00237457

Cartensen, K., \& Salzmann, L. (2016). The G7 Business Cycle in a Globalized World (5980). Retrieved from https://ssrn.com/abstract $=2815390$

Collins, S., Reiss, M., \& Stobart, G. (2010). What happens when high-stakes testing stops? Teachers' perceptions of the impact of compulsory national testing in science of 11-year-olds in England and its abolition in Wales. Assesment in Education: Principles, Policy and Practice, 17, 273 286. https://doi.org/10.1080/0969594X.2010.496205

Corbeil, P., \& Laveault, D. (2011). Validity of a simulation game as a method for history teaching. Simulation \& Gaming, 42(2), 462-475. https://doi.org/10.1177/2329490613516487

Dahar, R. L. (2015). Service quality and the training of employees: The mediating role of organizational commitment. Tourism Management, 46, 419-430. Retrieved from https://doi.org/10.1016/j.tourman.2014.08.001\%0A\%0A

David, B., Horth, M., \& Vehar, J. (2014). Becoming a Leader Who Fosters Innovation. Ccl®, August, 
$2-25$.

Deniz, K. (2007). A study on persuading students through speaking and listening at the second stage of the primary education. Ankara (Turkey): Unpublished PhD Thesis, Ankara (Turkey): Gazi University.

Denny, P. (2013). The effect of virtual achievements on student engagement. In M. W. E. et Al. (Ed.), Conference on Human Factors in Computing Systems (CHI 2013) (pp. 763-772). Paris, France.

Deterding, S., Sicart, M., Nacke, L., O'Hara, K., \& Dixon, D. (2011). Gamification: Using game-design elements in non-gaming contexts. In Proc. CHI EA '11 (pp. 2425-2428). ACM Press.

Dhar, R. L. (2015). Service quality and the training of employees : The mediating role of organizational commitment. Tourism Management, 46, 419-430. https://doi.org/10.1016/j.tourman.2014.08.001

Dyer, L., \& Reeves, T. (2000). Human Strategies and Firm Performance : What do we know and where do we need to go. International Journal of Human ResourceManagement, 6(3), 656-670. https://doi.org/10.1080/09585199500000041

Emmanuel, U., \& Ibewawuchi, E. (2015). Research Design and Sampling in Social and Management Sciences in 21 st Century. European Journal of Academic Essays, 2(3), 37-46.

Ferguson, G. (2002). Recent developments in the teaching of English for Specific Purposes. Unpublished classnotes, ICE, Univerwsity of Zaragoza.

Fisher, D. (2007). CMS-based simulations in the writing classroom: Evoking genre through game play. Computers and Composition, 24(2), 179-197. https://doi.org/10.1016/j.compcom.2006.06.004

Fruchter, R., \& Ponti, M. (2010). Distributing Attention across Multiple Social Worlds. AI \& Society, 25(2), 169-181.

Galetta, G., Meridionale, L., View, A. P., \& Galetta, G. (2014). The Gamification : Applications and Developments for Creativity and Education. In XVII International Creativity Conference: Creativity and Innovation in Education. Riga, Latvia: University of Cassino and Sourthern Lazio Uniclam - Italy. https://doi.org/10.13140/RG.2.2.24817.68965

Garris, R., Ahlers, R., \& Driskell, J. E. (2002). Games, motivation, and learning: A research and practice model. Simulation \& Gaming, 33(4), 441-4667.

Gino, F., \& Ariely, D. (2012). The dark side of creativity: Original thinkers can be more dishonest. Journal of Personality and Social Psychology, 102(3), 445-459. https://doi.org/10.1037/a0026406

Gordon, R. J. (2002). Innovation and Future Productivity Growth: Does Supply Create Its Own Demand? In C. Peter (Ed.), The Global Competitiveness Report 2002-2003 (pp. 253-275). New York: Oxford University Press.

Harris, A. (2008). Distributed leadership: According to the Evidence. Journal of Educational Administration, 46(2), 172-188.

Holton, E. F. I., \& BAldwin, T. T. (2003). Making Transfer Happen: An Action Perspective on Learning Transfer Systems. (E. F. I. Holton \& T. T. Baldwin, Eds.). San Francisco: Jossey-Bass.

Iksan, Z. H., Zakaria, E., Meerah, T. S. M., Osan, K., Lian, D. K. C., Mahmud, S. N. D., \& Krish, P. (2012). Communication skills among university students. Procedia - Social and Behavioral Sciences, 59, 71-76. https://doi.org/10.1016/j.sbspro.2012.09.247 
Kapp, K. M. (2014). The Gamification of Learning and Instruction Fieldbook: Ideas into Practice. San Francisco, CA, USA: John Wiley \& Sons.

Kay, J., Yacef, K., Maisonneuve, N., \& Reimann, P. (2006). The Big Five and Visualisation of Team Work Activity. In Intelligent Tutoring Systems: 8th International Conference, ITS 2006 (pp. 197-206). Jhongli, Taiwan: 0302-9743. https://doi.org/10.1007/11774303_20

Kiryakova, G., Angelova, N., \& Yordanova, L. (2014). Gamification in education. In Proceedings of 9th International Balkan and Science Conference.

Kraiger, K., \& Culbertson, S. S. (2013). ). Understanding and facilitating learning: Advancements in training and development. In Handbook of psychology: Vol. 12. Industrial \& organizational psychology (2nd ed., pp. 244-261). Hoboken, NJ: Wiley.

Landers, R. N., \& Callan, R. C. (2011). Casual social games as serious games: The psychology of gamification in undergraduate education and employee training. In M. M. A. Oikonomou \& L. C. Jain (Eds.), Serious games and edutainment applications (pp. 399-424). Surrey, UK: Springer.

Landers, R. N., \& Landers, A. K. (2014). An empirical test of the theory of gamified learn- ing: The effect of leaderboards on time-on-task and academic performance. Simulation \& Gaming, 45(6), 769-785. https://doi.org/10.1177/1046878114563662

Li, H., Liu, Y., Xu, X., \& Heikkila, J. (2013). Please stay with me! An empirical investigation on hedonic IS continuance model for social network games. In The 34th International Conference on Informatiion Systems. Milano, Italy.

Marczewski, A. (2012). Gamification: A Simple Introduction. Seattle. Seatle, WA: Kindle Edition.

McGonigal, J. (2011). Reality Is Broken: Why Games make Us Better and How They Can Change the World. New York: Penguin.

Miles, R. E., Miles, G., \& Snow, C. C. (2005). Collaborative Enterpreneurship: How Communities of Networked Firms Use Continuous Innovation to Create Economic Wealth. Stanford, CA: Stanford Business Books University Press.

Ninaus, M., Pereira, G., Stefitz, R., Prada, R., Paiva, A., Neuper, C., \& Wood, G. (2015). Game elements improve performance in a working memory training task. International Journal of Serious Games, 2(1), 2-16. https://doi.org/10.17083/ijsg.v2i1.60

Ormond, J. E. (2009). Educational Psychology (7th ed.). Pearson Prentice Hall.

Osipov, I. V, Volinsky, A. A., Nikulehev, E., \& Prasikova, A. Y. (2015). Study of Gamification Effectiveness in Online e- Learning Systems. International Journal of Advanced Computer Science and Applications, 6(2), 71-77.

Palmer, D., Lunceford, S., \& Patton, A. J. (2012). The engagement economy: how gamification is reshaping businesses. Deloitte Review, (11), 52-69. Retrieved from http://dupress.com/ periodical/deloitte-review/ 11:52-69 accessed 18 October 2013

Rahi, S. (2017). Research Design and Methods: A Systematic Review of Research Paradigms, Sampling Issues and Instruments Development International Journal of Economics \&. International Journal of Economic \& Management Sciences, 6(2), 1-5. https://doi.org/10.4172/2162-6359.1000403

Ramus, T., \& Vaccaro, A. (2017). Stakeholders matter: How social enterprises address mission drift. Journal of Business Ethics, 143(2), 2307-2322. https://doi.org/10.1007/s10551-014-2353-y

Reiners, T., Wood, L. C., Chang, V., Guetl, C., Herrington, J., Teräs, H., \& Gregory, S. (2012). 
Operationalising gamification in an educational authentic environment. In P. Kommers, T. Issa, \& P. Isaías (Eds.), IADIS International Conference on Internet Technologies \& Society 2012 (pp. 93-100). Perth, Wesstern Australia: Australia.

Robinson, J., Lewars, T., Perryman, L. S., Crichlow, T., Smith, K., \& Vignoe, J. (2000). Royal flush: A cross-cultural simulation. Business Communication Quarterly, 63(4), 83-94. https://doi.org/10.1177/108056990006300408

Russell, D., \& Fisher, D. (2009). Online, multimedia case studies for professional education: Revisioning concepts of genre recognition. In J. Giltrow \& D. Stein (Eds.), Genres in the Internet: Issues in the theory of genre (pp. 163-192). Amsterdam, Netherlands: Benjamins.

Santrock, J. W. A. (2007). Topical Approach to Life Span Development. McGraw-Hill Companies, Inc.

Shpakova, A., Dörfler, V., \& Macbryde, J. (2017). Changing the game: a case for gamifying knowledge management. Technology and Sustainable Development, 14(2), 143-154. https://doi.org/10.1108/WJSTSD-01-2017-0002

Simões, J., Díaz, R., \& Fernández, A. (2013). Computers in Human Behavior A social gamification framework for a K-6 learning platform. Computer in Human Behavior, 29(2), 345-353. https://doi.org/10.1016/j.chb.2012.06.007

Skarzauskiene, A. (2015). Fostering collective creativity through gamification. In The ISPIM Americas Innovation Forum 2014. Montreal, Canada.

Sternberg, R. J. (2007). A systems model of leadership: WICS. American Psychologist. Leasership, 62(1), 34-42.

Stoll, L. (2007) Creative leadership: a challenge of our times. Paper presented at the International Congress for School Effectiveness and Improvement Auckland, New Zealand.

Tierney, P. (2008). Leadership and employee creativity. (J. Zhou \& C. E. Shalley, Eds.) (Handbook). New York: NY: Erlbaum.

Torrance, E. P., Fitzgerald, K., \& Batson, A. (2000). The Rationale and Validation of the Torrance Tests of Creative Thinking, Verbal and Figural. Tempo, $X X(2), 1-35$.

Werbach, K. (2014). (Re)defining gamification: a process approach. Persuasive Technology, 8462, 266-272.

Werback, K., \& Hunter, D. (2012). For the Win: How Game Thinking Can Revolutionize Your Business. Philadelphia: Wharton Digital Press.

Wilson, K. A., Bedwell, W. L., Lazzara, E. H., Salas, E., Burke, S. C., Estock, J. L., \& Conkey, C. (2009). Relationships between game attributes and learning outcomes. Simulation \& Gaming, 40, 217-266.

Witte, A. E. (2014). Serious games: A seminar map for international business schools. Business and Professional Communication $\quad$ Quarterly, 31-49. https://doi.org/10.1177/2329490613516487

Woodcock, R. J., \& Crow, C. (2010). Social Work Practice Strategies and Professional Identity within Private Fostering: A Critical Exploration. Adoption and Fostering, 34, 41-51.

Zhang, X., \& Bartol, K. M. (2010). Linking Empowering Leadership and Employee Creativity: The Influence of Psychological Empowerment, Intrinsic Motivation, and Creative Process Engagement. Aca, 53(1), 107-128. 
Zicherman, G., \& Cunningham, C. (2011). Gamification by Design: Implementing Game Mechanics in Web and Mobile App. Sebastopol, CA: O'Reilly Media.

Zimmerer, T., \& Scarborough, N. (2008). Essentials of Entrepreneurship and Small Business Management. Upper Saddle River, NJ: Prentice-Hall. 